\title{
The Relative Impact of Monetary and Fiscal Actions on Economic Activity: A Cross-Country Comparison
}

\author{
DALLAS S. BATTEN and R. W. HAFER
}

\begin{abstract}
WONSIDERABLE research has been devoted to assessing the empirical relationship between both monetary and fiscal actions and economic activity in the United States. Much of this research was sparked by the controversial restits obtained from investigating the impact of monetary and fiscal actions on GNP using the "S€. Louis equation." "The St. Louis results can be summarized neatly: monetary actions have a significant, permanent effect on nominal GNP growth, while fiscal actions exert no statistically significant, lasting influence.
\end{abstract}

This paper is a shortened version of an earlier study presented in seminars at De Nederlandsche Bank N. V., Erasmus University and at the 1982 Southern Economic Association meetings. We wish to express our thanks to all the participants at these sessions.

the original articles presenting the controversial results are Leonall C. Andersen and Jerry L. Jordan, "Monetary and Fiscal Actions: A Test of Their Relative Importance In Economic Stabilization," this Review (November 1968), pp. 11-24; and Leonall C. Andersen and Keith M. Carlson, "A Monetarist Model for Economic Stabilization," this Review (April 1970), pp. 7-25.

Early critics include Frank De Leeuw and John Kalchbrenner, "Monetary and Fiscal Actions: A Test of Their Relative Importance in Economic Stabilization - Comment," this Review (April 1969), pp. 6-11; Richard G. Davis, "How Much Does Money Matter? A Look at Some Recent Evidence," Federal Reserve Bank of New York Monthly Review (June 1969), pp. 119-31; and Edward M. Gramlich, "The Usefulness of Monetary and Fiscal Policy as Discretionary Stabilization Tools," Journal of Money, Credit, and Banking (May 1971), pp. 506-32.

More recent sparring over the same issues is reported in Benjamin M. Friedman, "Even the St. Louis Model Now Believes in Fiscal Policy,"Journal of Money, Credit, and Banking (May 1977), pp. 365-67; Keith M. Carlson, "Does the St. Louis Equation Now Believe in Fiscal Policy?" this Review (February 1978), pp. 13-19; and n. W. Hafer, "The Role of Fiscal Policy in the St. Louis Equation," this Review (January 1982), pp. 17 -22.
Substantially less work has been conducted within this framework for countries other than the United States. ${ }^{2}$ Consequently, it is uncertain whether the St. Louis approach can be used universally in evaluating the economic impact of monetary and fiscal actions on income growth.

This study investigates the generality of the St. Louis approach by applying it to other countries. Based on evidence generated from the study of six developed countries - Canada, France, Germany, Japan, the United Kingdom and the United States we conclude that money growth is more important than fiscal actions in determining GNP growth. Moreover, our results are robust across the "fixed" and "flexible" exchange rate regimes that characterized the past two decades.



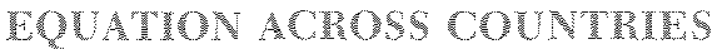

The St. Louis equation typically estimated for the United States consists of only three variables: nominal

\footnotetext{
${ }^{2}$ Two exceptions are Michael W. Keran, "Monetary and Fiscal Intluences on Economic Activity: The Foreign Experience," this Review (February 1970), pp. 16-28; and William G. Dewald and Maurice N. Marchon, "A Modified Federal Reserve Bank of St. Lotis Spending Equation for Canada, France, Gemany, Italy, the United Kingdom and the United States, "Kredit und Kapital (Heft 2 1978), pp. 194-212.

Our approad differs from these and other works in that a) we focus solely on the growth-rate version of the St. Louis equation (see footnote 6); b) we jettison the comnonly ised polynomial estimation technique for unconstrained ondinary least squares (see footnote 8); c) we explicitly examine the stability of the underlying relationships from each conntry over time; and d) we extend the sample period studied.
} 
GNP, a variable summarizing monetary actions and one summarizing fiscal actions. Because the equation is formulated solely to test the relative efficacy of monetary and fiscal actions, it is not intended to incorporate all of the exogenous forces that affect nominal GNP. Conceptually, therefore, the equation is misspecified. This conceptual misspecification poses a statistical problem, however, only if the omitted exogenous variables are correlated with the policy measures used in the equation. ${ }^{3}$ If, as assumed generally, the "missing" exogenous variables are neither policy variables nor closely correlated with the variables representing monetary and fiscal actions, their omission does not pose a serious statistical problem. ${ }^{4}$

This discussion implicitly assumes that the domestic economy being analyzed is relatively "closed" to the rest of the world. While this may adequately characterize the United States, it is not true for countries whose exports account for a large proportion of their GNP. In addition, because monetary and fiscal actions obviously affect the foreign sector, the correlation between external and domestic infuences on GNP rises as the economy becomes more open. Consequently, these external influences should be included in analyzing the relative impacts of monetary and fiscal actions on GNP in such "open" economies.

In response both to past criticism of the St. Louis equation and the likely interrelation of domestic and

${ }^{3}$ For examples of the specification error argument, see Franco Modigliani and Albert Ando, "Impacts of Fiscal Actions on Aggregate Income and the Monetarist Controversy: Theory and Evidence," in jerome L. Stein, ed., Monetarism, vol. I, Studies in Monetary Economics (Noth-Holland. 1976), pp. 17-42; and Robert I. Cordon, "Comments on Modigliani and Anto," in Monetarism, pp. 52-66.

To understand the necessary condition for bias due to misspecification, consider the following equation:

(1) $\mathrm{X}_{t}=\mathrm{a}_{4}+\mathrm{a}_{\mathrm{a}} \mathrm{X}_{t}+\mathrm{e}_{3}$

Now if equation I' is not the "true" model, but some other exogenots variable, $Z$, has been onitted, the true nodel is:

(2) $Y_{l}=b_{0}+b_{1} X_{t}+b_{2} Z_{1}+\eta_{t}$.

Estimating equation l' instead of 2 ' yields an estimate of a, with an expected value of $a_{1}+\hat{\lambda}_{1} b_{2}$ where $\hat{\lambda}_{1}$ is obtained by estinating

(3') $Z_{t}=\lambda_{19}+\lambda_{1} X_{t}+\phi_{t}$

Obviously, the estimate of a is biased only if $\hat{\lambda}_{1} \neq 0$ but $\hat{\lambda}_{1}$ equals $r_{y, x}\left(\frac{S}{S}\right)$ where

$\Gamma_{x:}=$ the simple corretation coefficient between $X$ and $Z_{2}$ and

$S_{i}$ - the stardard deviation of $i$

Consequently, $\hat{\lambda}_{1} \neq 0$ only if $r_{\mathrm{r}} \neq 0$; that is, $X$ and $Z$ must be correlated before the omission of $Z$ results in a specification error.

"This point also is made in Andersen and Jordinn, "Monetary and Fiscal Actions." p), 24 external influences on GNP in other countries, the following modified version of the St. Louis equation is used:

$$
\text { (1) } \begin{aligned}
\dot{\mathrm{Y}}_{\mathrm{i}}=\alpha_{0} & +\sum_{\mathrm{i}=0}^{\mathrm{J}} \mathrm{m}_{\mathrm{i}} \dot{\mathrm{M}}_{\mathrm{t}, \mathrm{i}}+\sum_{\mathrm{i}=0}^{\mathrm{K}} \mathrm{g}_{\mathrm{i}} \dot{\mathrm{G}}_{\mathrm{t}-\mathrm{i}} \\
& +\sum_{\mathrm{i}=0}^{\mathrm{L}} \epsilon_{\mathrm{i}} \dot{\mathrm{EX}} \mathrm{X}_{\mathrm{i}-\mathrm{i}}+\varepsilon_{\mathrm{t}}
\end{aligned}
$$

where $\mathrm{Y}, \mathrm{M}, \mathrm{G}$ and $\mathrm{EX}$ represent $\mathrm{GN} \mathrm{P}$, narrow money (M1), federal government expenditures and merchandise exports, respectively. ${ }^{5}$ The dots above each variable indicate that the equation is estimated in growth rate form. ${ }^{6}$ The appropriate lag lengths $(J, K$ and $L$ ) are determined using an orthogonal regression procedure with sequential hypothesis testing. ${ }^{i}$

Finally, one additional modification is made in estimating the equation. The St. Louis equation typically is estimated with each distributed lag's coefficients restricted to lie on a fourth-degree polynomial with endpoints constrained to equal zero. Because these constraints may not be valid across countries, we esti-

\footnotetext{
${ }^{5}$ Even though many contries included in this study do not explicitly target the narrow (MI) definition of money, this definition provides a consistent and comparable set of explanatory variables acress countries. Also, to remove the impact of cyclical changes, high-employment government expenditures is the measure of fiscal policy action typically included in the estimation for the United States. Becase comparable measures of government expenditures do not exist for the other countries in the sample, federil government expenditures that are not adjusted for cyclical changes are used for each country. It should be noted, however, that using either measure for the United States did not alter the conclusions reached in this paper.
}

Furthermone, a criticism frequently leveled at using OLS to estimate equation 1 is that the right-hand-side variables are not exogenous with respect to GNP, resulting in simultaneous equation bias. This issue is addressed in an eartier, expanded version of this paper through the use of Granger type causality tests. These tests did not indicate any causal relationship from income growth to noney growth or government expenditure growth in any of the comtries analyzed. Alternatively, income growth appears to "cause" export growth in France and the United States, but not in the remaining conntries. Statistically speaking then, the estimated parameters of equation 1 , as specified for the United States and France, may be biased. This does not appear to be the case for the rest of the sample.

CCarson, "Does the St. Lours Equation Now Believe in fiscal Policy?" demonstrates that the original firstedifference form of the model, when updated through the 1970 s, is plagued by heteroscedasticity. This problem is not evident in the growth rate version, however.

"This procedure involves a Gram-Schmilt orthogonalization of the data and the use of a testing procedure introduced by Marcello Pagano and Michael I. Hartley "On Fitting Distribated Lag Models Subject to Polynomal Restrictions,"Journal of Econometrics June 1981), pp. 17I-98; and extended by Dallas $\$$. Batten and Danel E. Thornton, "Polynomial Distributed Lags and the Estimation of the St. Lous Equation," this Review (forthoming). 


\section{Table 1}

\section{Summary of Estimation Results ${ }^{1}$}

\section{Country and Sample Period}

\begin{tabular}{|c|c|c|c|c|c|c|}
\hline Coefticient & Montivis & fronces & cerrasty & 176041180 & 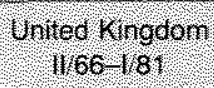 & $\begin{array}{l}\text { United states } \\
162 \text { 1/82 }\end{array}$ \\
\hline Constant & $4+4006$ & 4047 & $\begin{array}{l}007 \\
(131)\end{array}$ & $(1,65)$ & $(0.21)$ & $(9.94)$ \\
\hline $\mathrm{sin}$ & $(34)^{2}$ & $(1,75)^{2}$ & $(350)$ & $(356)^{2}$ & $(2.51)^{2}$ & $\begin{array}{l}1094 \\
(4.29)\end{array}$ \\
\hline ra & 4.9011 & 4,192 & $\left(\begin{array}{l}225 \\
(1.44)\end{array}\right.$ & (0.87) & $(2,845$ & $\begin{array}{r}199 \\
(1.21)\end{array}$ \\
\hline sex & $\left(1.543^{2}\right.$ & $(324)$ & $\begin{array}{l}376^{2} \\
(2,48)\end{array}$ & $\left(\begin{array}{l}067 \\
(1,65)\end{array}\right.$ & $(3.02)$ & $(1.64)$ \\
\hline$n^{2}$ & 49 & 82 & 29 & 19 & 159 & 47 \\
\hline SE & 006 & 008 & ४011) & 0.6 & 013 & 008 \\
\hline DW & $\left(\begin{array}{l}92 \\
(30)\end{array}\right.$ & 2.09 & $\sqrt{91}$ & 179 & 2.04 & 224 \\
\hline
\end{tabular}

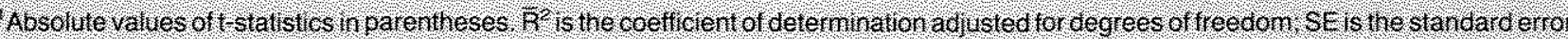
of the regression and DW is the Dubinhatson test statistic.

'Statistically significant at hio 5 percent level using a ove-taled tost.

${ }^{3}$ Estrnate of ho the tirst order serial correlation coeficient.

mate equation 1 using unconstrained ordinary least squares (OLS) instead of subjecting the data to potentially invalid polynomial restrictions. 8

Equation 1 is estimated using grarterly data from Canada, France, Germany, Lapan, the United Kingdom and the United States. A summary of the OLS regression results is reported in table 1 . (The detailed results can be found in the appendix.) The sample periods differ due to differences in data avalability. The regressions exhibit a relatively wide range of explanatory power in describing GNP growth in the

${ }^{8}$ For a discussion of the possible effects of using polynomal and endpoint restrictions, see Peter Schmidt and Roger N. Waud, "The Almon Lag Technique and the Monetary Versus Fiscal Policy Debate,"Journal of the American Statistical Association (March 1973), pp. $11-19$

The imposition of polvzomial and endpoint constraints is motivated primarily by the desire to estimate more precisely coefficients of highly colizear variables fa common characteristic of distributed lag models). Our concern, in contrast is the total or camulative impact of monetary and fiseal actions on GNP growth. Consequently, OLS will yedd estimates of linear combinations of coefficients that ane as precise as those obtained by imposing polynomal and endpoint restrictions. See Henri Theil Principles of Econometrics (John Wiley and Sons, Ine, 1971), pp. 147-52.

When estinated for France, equation I also contains a dummy fariable representing the stadent riots and subsequent nationwide strikes that occurred in $\mathbf{L} / 1968$. different economies: the $\overline{\mathbf{R}}^{2}$ varies from a high of .82 in France to a low of 19 in Japan. The Durbin-Watson statistics indicate that the estimates generally are not plagued by first-order serial correlation problems. In only one instance, that of Canada, is a first-order serial correlation correction technique necessary. As shown in table 1 , this correction (rho is estimated to be , 30) adequately removes the problem.

\section{The Unied Strtes}

The "standard" results appear to hold for the United States; that is, they are not affected significantly by our modifications. The summed impact of money growth is significantly positive $(t=4.29)$ and does not differ from unity $(t=0.37)$. This means that a 1 percentage-point increase in money growth leads to a permanent 1 percentage-point rise in GNP growth. Moreover, the estim mated coefficients for the individual lag terms (see appendix) suggest a large effect of money on income during the first three quarters, with a varying impact throughout the remaining lag terms.

The estimated coefficients for the fiscal measure are interesting because they indicate only a minor initial effect on income growth with a mostly negative impact thereafter. This is supported by the cumulative effect 
of fiscal policy being negative and negligible $(\Sigma g=$ $-0.199)$, and statistically insignificant $(t=-1.21)$.

The results obtamed for exports are similar to those for fiscal actions: none of the individual coefficients are large in absolute magnitude compared with those of $\dot{M}$ or $\dot{G}$, and most are statistically insignificant. Moreover, the cumulative effect of export growth on GNP growth is not statistically significant at any conventional level.

Thus, the standard St. Louis equation results continue to hold for the United States even with the changes in the specification: money growth exerts a significant, lasting impact on income growth; government expenditure growth and export growth have only transitory influences at best. With these results forming the basis for comparison, we will now examine what the application of this framework produced in the other countries.

\section{The maret of Monat}

Looking first at the effects of changes in money growth, we observe that the qualitative results for each country are quite similar to those for the United States. Specifically, changes in money growth have a statistically significant, permanent impact on nominal income growth in each country. ${ }^{10}$ The quantitative results, however, exhibit some differences. The cumulative impact of money growth for each country except Cana* da is noticeably smaller than it is for the United States. For Canada. the camulative impact is not statistically different from one $(t=1.29)$. Thus, while changes in money growth exert a positive, statistically significant influence on the growth of income across all the economies studied, a 1 percentage-point increase in money growth results in a less than 1 percentage-point rise in income growth for all of the countries except the United States and Canada.

\section{The Intun of ment Actions}

The results of changes in fiscal actions are interesting because they tend to confirm the U.S. findings. The cumulative impact of a change in the growth of government expenditures on income growth is statistically significant for the United Kingdom and France. For the remaining countries, however, the cumulative impact is negligible and, for Canada and Germany the variable takes on an unexpected negative sign. Moreover, the cumulative impact of a change in fiscal

\footnotetext{
${ }^{10}$ Bectuse the expected cumulative impact of each variable in equation 1 is positive, one-tailed lypothesis tests are employed.
}

actions is smaller than that of a change in money growth in each country.

\section{The manct of Exponts}

Not surprisingly, export growth is an important factor in explaining GNP growth for the countries in our sample other than the United States and Japan. ${ }^{11}$ The cumulative impact is statistically significant and ranges in magnitude from 0.54 in Canada to 0.21 in the United Kingdom. Consequently, it appears that the inclusion of export growth is an important modification of the St. Louis equation for explaining economic activity in open economies, ${ }^{12}$

\section{置 WOPKS, BUY}

The comparison of the empirical results from a variety of countries indicates that the St. Louis equation is useful in assessing the relative impact of monetary and fiscal actions, and that its explanatory power can be increased with the addition of export growth as an explanatory variable. Furthermore, the evidence here suggests that changes in money growth have a permanent and significant influence on GNP growth. The evidence does not provide a similar conclusion for fiscal actions, except for the United Kingdom and France.

The usefulness of any equation that purports to explain macroeconomic phenomena depends crucially on the stability of the estimated relationship. This issue is even more significant if some of the right-hand-side variables in the estimated equation are policy. determined. ${ }^{13}$ Consequently, it is always impottant to

\footnotetext{
"The export results for fapan are not strprising even though the general perception of Japan is that of a large exporter. Japan's export sector as a percent of rominal GNP is actually quite low relative to other countres in on sample. Fot example, in 1980 Japan s exports accounted for only 12 percent of GNP. In comparison, the figures for the other countries are: United States is perent); Canala (27 percent); United Kingdon (2I percent); France ( 18 percent); and Gemany (24 percent).

${ }^{12}$ When equation 1 is estimated excluding the distributed lag of export growth, the cualitative resalts for France are the only ones affected. In that case, the cumblative impact of a change in money growth is no longer statistically significant (even at the 10 percent level). Furthernore, there is little change in the quantitative results concerning the combulative impacts of either monetayy or fiscal actions. This finding is comforting given the discussion in footnote 5 .

13The argiment is that if estimated parameters change with policy changes, then there is no stable foundation upon which policy makers may project the outeome of today's actions into the future. This argument is presented in Robert $\mathrm{E}$. Lucas, Jr. "Econometric Policy Evaluation: A Critique," in Karl Brumer and Allan A. Meltrer, eds., The Phillips Curce and Labor Markets, vol. I (1976). The Carnegie-Rochester Conference Series on Public Policy, Supplement to the Journal of Monetary Economics, pp. 1946 .
} 
examine the statistical stability of the estimated parameters across alternative policy rules if the eqtation is being used in policy analysis.

Although the determination of each policy shift in each comntry is a task well beyond the scope of this paper, there is a single event common to all of the countries that can be used to assess the stability of the estimated relationships. That event, which oceurred during the early 1970 s, is the collapse of the Bretton Woods system. In general, the period before the second quarter of 1973 is viewed as a fixed exchange rate regime while the period since then usually is characterized as a floating exchange rate period. ${ }^{1: 4}$ While one may quibble about this characterization, the early 1970 s would seem to mark a significant turning point in the implementation of domestic monetary and fiscal policies for the open economies in our sample. Consequently, this apparent policy shift provides a useful point to test the stability properties of the estimated income relationships. ${ }^{15}$

It is essential to understand that we are investigating the stability of the relationship that explains the transmission of changes in money growth and government expenditure growth, however determined, to changes in GNP growth. We are not concerned with how or why a change in money growth or government expenditure growth occurs; we simply wish to determine the extent to which these variables affect the growth of nominal GNP. Consequently, the use of the exchange. rate regime change does not require monetary or fiscal actions to have any greater or lesser effect on GNP growth after the break than before. The change in

\footnotetext{
1:The break points for the United Kingdem and Canada tested are slightly different from the $/ 1973$ point. See text.

${ }^{15}$ It is typicaly thought that during a fixed exchange rate regime the reserve currency conntry determmes monetary policy for the rest of the world. If this were the case, the measured influence of monetary actions on econonic activity during the Bretton Woods period actually would indicate actions motivated by the reserve currency country, not by the domestic monetary athorities. To test this proposition, we performed Granger-type causality tests to see if changes in U.S. money growtl" "caused" changes in foreign money growth diring the fixed exchange rate period. These tests results did not indicate any systematic relationship between U.S. money growth and money growth in any of the countries included in our sample. Our results support those of Edgar L. Feige and James M. Johamnes, "Was the United States Responsible for Worldwide Inflation Under the Regine of Fixed Exchange Rates?" Kuklos (Fasc. 21982), pp. 263-77; and Edgar L. Feige and Kenneth J. Singleton, "Multinational Inflation Under Fixed Exchange Rates: Some Empirical Evidence From Latent Variable Models," The Review of Economics and Statistics (February 1981), pp. 11-19. Consequently, comnecting observed money growth with monetary policy decisions in these contuties, even during the fixed exchange rate period, appears to bave some empirical support.
}

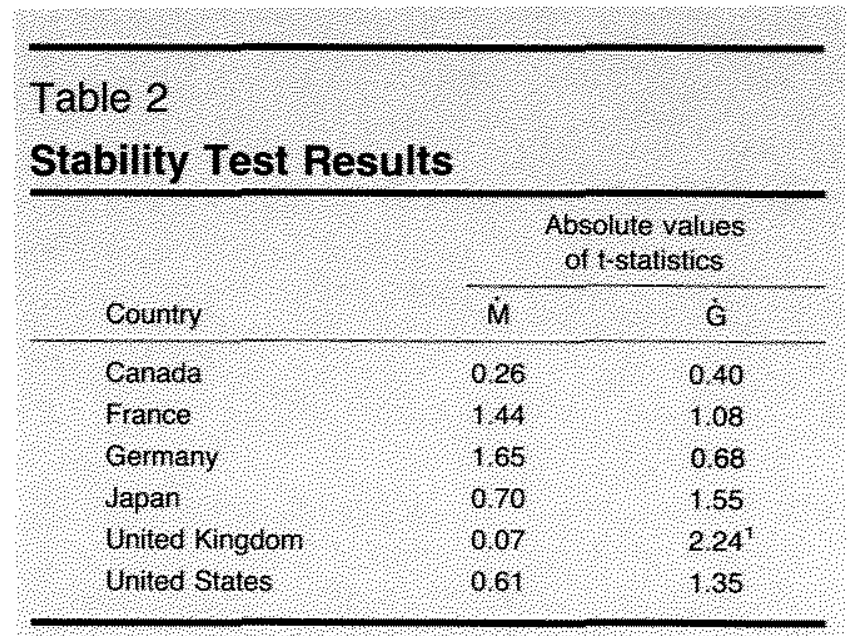

Statistically signilicant at 5 percent level

exchange rate regimes is chosen as a likely break in the income equations primarily because of its universality.

To examine the stability of the estimated income relaiionships, $(0,1)$ dummy variables are used to form multiplicative slope-dummy terms for the money growth and government expenditure growth variables. Stability is investigated by testing the hypothesis that the cumulative impact of each dummied variable's distributed lag is significantly different from zero. ${ }^{16}$ If the resulting $t$-statistic is less than a predetermined critical value, the null hypothesis that these coefficients are stable across exchange rate regimes cannot be rejected.

The calculated t-statistics for each variable's stability test are reported in table 2 . The break point for the United States, France, Germany and Japan is $1 / 1973$, the widely accepted timing of the breakdown of the

\footnotetext{
"This approach is swggested by Damodar Cujarati, "Use of Dummy Variables in Testing for Equality Between Sets of Coefficients in Linear Regressions: A Generalization," The Anerican Statistician (December 1970), pp. 18 22. We employ this method by constructing a slope-dumny term for each variable in the distributed lag of $\dot{M}$ and of $\dot{C}\left(e, g, \overline{D M}_{t}=D \cdot \dot{M}_{k}\right.$ where $\mathrm{D}=0$ in the fixed rate period and $I$ in the floating-rate period). The hypothesis that the cumulative impact of $\mathrm{i}$ has changed with the movement of foating exchange rates is then investigated by testing $\sum_{i=0}^{\mathrm{K}} \dot{\mathrm{DM}}_{\mathrm{t}-1}=0$. A similar procedure is used for $\dot{G}$.

This approach is chosen over the more commonly used Chow test, because the Chow test examines the stability of the entire relationship. Thus, the coefficients of one variable nay change dramatically over time, while the Chow test will not reject the hypothesis of stability if that variable's explanatory power is weak relative to that of other variables whose coefficients are relatively stable. The dummy variable approach circumvents this potential problem.
} 
Smithsonian extension of the Bretton Woods system. Because the United Kingdom and Canada had refused earlier to peg the value of their currencies to the U.S. dollar, the break points tested are II/1972 and II/1970 for the United Kingdom and Canada, respectively. The results reported in table 2 support the hypothesis that in each country the cumulative impact of a change in money growth is stable across the break in exchange rate regimes. The cumulative inpact of a change in the growth of government expenditures exhibits instability only for the United Kingdom.

The results for the United Kingdom indicate that the estimated equation does not reliably capture the relationsh ip between changes in the growth of government expenditures and GNP growth. Furthermore, a shift in the trend rate of velocity growth captured by the constant term) is detected. To correct for both of these deficiencies, equation 1 is re-estimated for the fullsample period with the coefficients of government expenditure growth and the constant term allowed to take on different values during the two exchange rate periods. The rewestimated United Kingdom equation is (absolute value of $t$-statistics in parentheses):

$$
\begin{aligned}
& \dot{\mathrm{Y}}=\underset{(1.05)}{0.008}-\underset{(1.90)}{0.024 \mathrm{DL}}+\underset{(2.12)}{0.679} \underset{\mathrm{i}=0}{\stackrel{11}{\mathrm{\Sigma}}} \dot{\mathrm{M}}_{\mathrm{t}-\mathrm{i}} \\
& -0.043 \sum_{i=0}^{2} \dot{G}_{t-1}^{I}+0.530 \sum_{i=0}^{2} \dot{G}_{t-1}^{11} \\
& +0.200 \stackrel{2}{\Sigma} \dot{E X}_{t-i} \\
& \text { (2.95) } \mathrm{i}=0 \\
& \overline{\mathrm{R}}^{2}=0.66 \quad \mathrm{SE}=0.012 \quad \mathrm{DW}=2.15
\end{aligned}
$$

These results indicate that, after separating the in fluence of government expenditures and the constant term into the two periods, the cumulative effect of changes in British money growth increases in magnitude and remains positive and significant and now is not statistically different from one $(t=1.00)$.
This suggests that the failure to incorporate the secular decline in the trend rate of velocity growth since 1973 seriously understated the initially estimated impact of changes in money growth. Export growth continues to influence GNP growth significantly, although the summed coefficient indicates a slight decline.

The United Kingdom estimates indicate that the govermment expenditure results in table 1 are capturing the post-1I/1972 effects. For the period II/1966 to 11/1972, fiscal actions have no significant lasting effect on income growth. The post-IV/1972 results, on the other hand, point to a significant and fairly substantial fiseal effect. The post $-11 / 1972$ results indicate that increasing the growth of government expenditures by 1 percentage point will permanently increase income growth by about one-half as much. Thus, in contrast to the evidence presented for the other countries examined, the cumulative impact of fiscal actions is highly significant only in the United Kingdom, and then only after $\mathrm{II} / 1972$.

\section{SUMMAII}

The results in this paper demonstrate that the St. Louis equation can be applied to a variety of other countries and that monetary actions dominate fiscal actions in determining the pace of economic activity in these countries. Estimating a modified St. Louis equation for six different countries, our results indicate that changes in money growth have a significant and lasting impact on nominal income growth in all six cases. Of equal importance, the money GNP link was stable in each country across one of the most significant international policy shifts of the last two decades - the move from fixed to floating exchange rates.

In contrast, fiscal actions are significant only in the United Kingdom and France. Moreover, this effect does not appear to be stably related to income in the United Kingdom where fiscal actions have exerted a lasting impact on income growth only during the recent floating exchange rate period. 


\section{Appendix Detailed Estimation Results ${ }^{1}$}

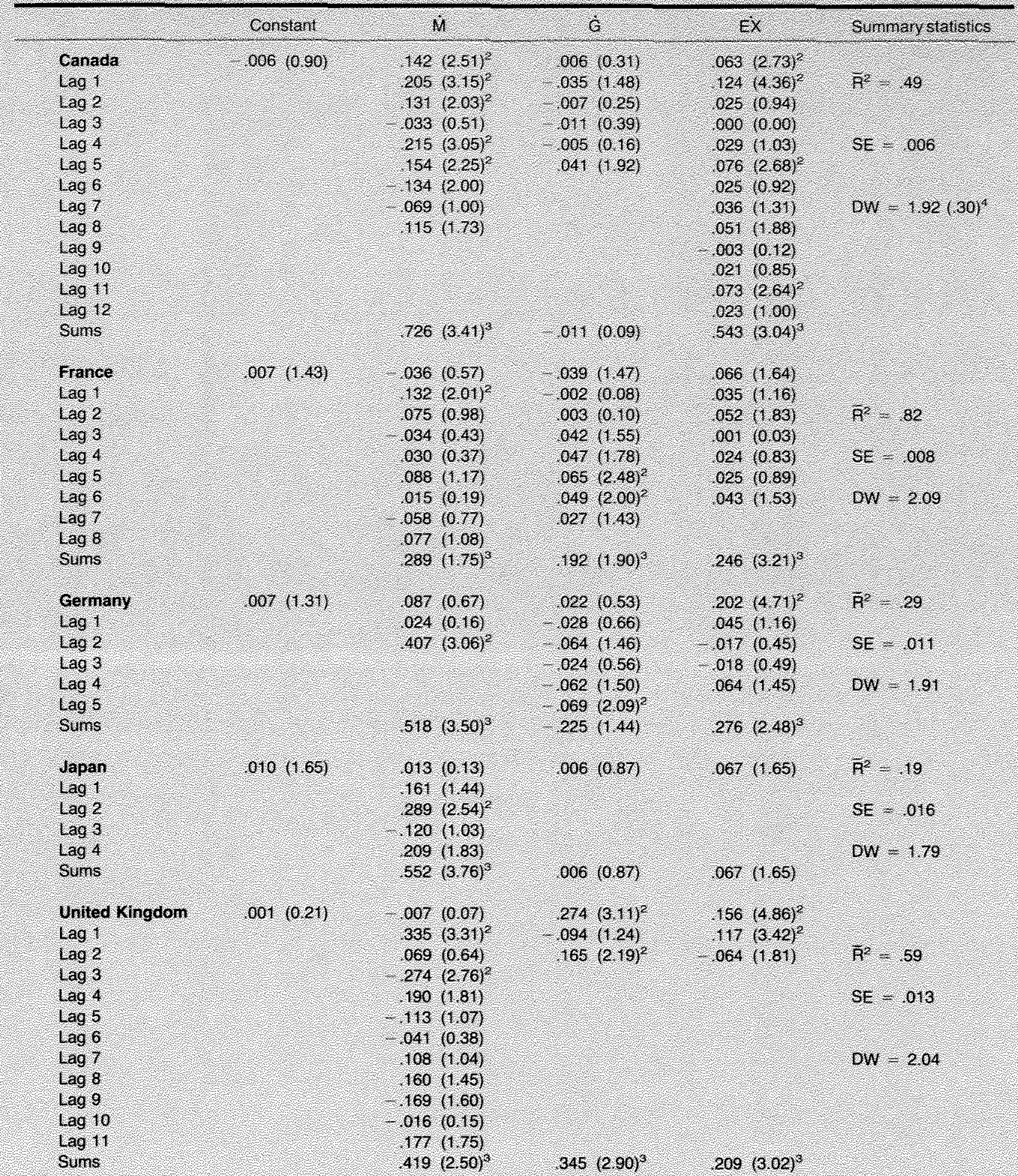




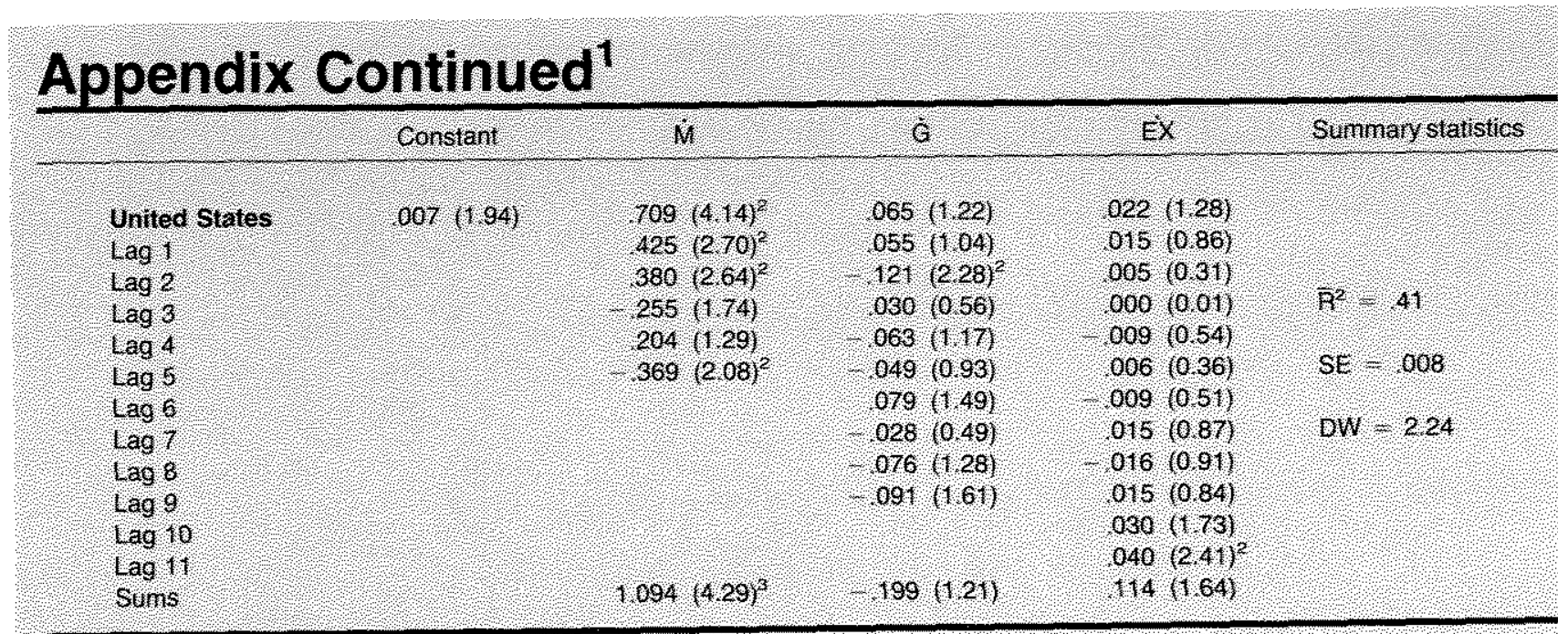

'See notes accompanying table

Statistically signilant at he 5 percent level using a two talled test istatsticaly significant at he 5 percent level ushtg o one-tailed lest

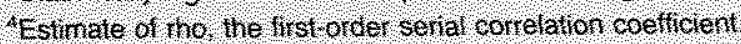

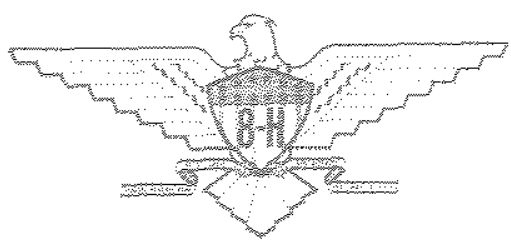

